\title{
PEMAKNAAN RUANG TERBUKA PUBLIK TAMAN BUDAYA YOGYAKARTA SEBAGAI PUSAT KESENIAN DAN KEBUDAYAAN DI YOGYAKARTA
}

\author{
Serafiani Turkaemly Eka Putri ${ }^{1}$, Anna Pudianti ${ }^{{ }^{\star}}$ \\ 1,2 Program Studi Magister Arsitektur, Fakultas Teknik, Universitas Atma Jaya Yogyakarta \\ Jalan Babarsari No.3 Sleman DIY, 55281 \\ anna.pudianti@uajy.ac.id
}

Diterima: 10-09-2020Ｄireview : 20-09-2020 Direvisi : 09-01-2021 Disetujui: 09-01-2021

ABSTRAK. Tujuan penelitian adalah untuk mengetahui bagaimana makna ataupun nilai dari Taman Budaya Yogyakarta bagi masyarakat mengingat keberadaannya sebagai pusat kesenian dan kebudayaan di Yogyakarta. Setiap ruang publik seharusnya tidak hanya hadir secara fisik akan tetapi dapat memberi rasa atau makna tersendiri bagi kota ("places" matter most), bagaimana suatu ruang publik dapat memenuhi kebutuhan masyarakat kota akan adanya sebuah wadah interaksi sosial antar masyarakat. Taman Budaya Yogyakarta merupakan salah satu ruang publik yang dijadikan masyarakat sebagai tempat berekreasi serta aktivitas seni dan kebudayaan. Taman Budaya Yogyakarta atau yang dulu disebut dengan Purna Budaya, pertama kali dibangun pada tanggal 11 Maret 1977 di daerah kawasan Universitas Gadjah Mada. Taman Budaya dibangun kembali pada tahun 2002 di Kawasan Gondomanan. Metode yang digunakan adalah dengan melakukan wawancara secara online melalui aplikasi WhatsApp serta metode studi pustaka. Hasilnya, diketahui bahwa Taman Budaya Yogyakarta memiliki makna kultural, makna sosial (interaksi individu dengan lingkungannya), makna pentingnya relasi antar manusia, dan memiliki makna harmonisasi kehidupan sosial dan budaya. Makna suatu ruang publik bisa terbentuk dari tatanan serta keadaaan fisik ruangnya.

Kata kunci: Makna, Ruang Terbuka Publik, Taman Budaya Yogyakarta

ABSTRACT. The study aims are to discover the meaning or value of the Taman Budaya Yogyakarta for the community, given its existence as a center for arts and culture in Yogyakarta. Every public space should not only be physically present. Still, it can give a sense or meaning to the city ("place" matters most), how public space can meet the needs of the city community for a place of social interaction between communities. Taman Budaya Yogyakarta is one of the public spaces used by the community as a place of recreation and artistic and cultural activities. Taman Budaya Yogyakarta or formerly called Purna Budaya was first built on March 11, 1977, in the area of Gadjah Mada University. The Cultural Park was rebuilt in 2002 in the Gondomanan Region. The method used is to conduct online interviews through the WhatsApp application and literature study method. As a result, it is known that the Taman Budaya Yogyakarta has a cultural meaning, a social meaning (the interaction of individuals with their environment), the importance of relationships between people, and the meaning of harmony in social and cultural life. The meaning of a public space can be formed from the physical structure and condition of the space.

Keywords: Meaning, Public Space, Taman Budaya Yogyakarta

\section{PENDAHULUAN}

Yogyakarta dikenal sabagai salah satu daerah di Indonesia dengan budaya lokalnya yang kental sehingga menjadi salah satu tujuan wisata di Indonesia bagi wisatawan lokal maupun mancanegara. Budaya Yogyakarta tersebut mampu meningkatkan pendapatan daerah maupun negara melalui sektor pariwisatanya. Salah satu fasilitas kebudayaan yang dimiliki Yogyakarta saat ini adalah Taman Budaya Yogyakarta.

Taman Budaya Yogyakarta berada di Jalan Sriwedani No.1, Ngupasan, Gondomanan,
Yogyakarta. Letak kawasan Taman Budaya Yogyakarta yang berada di pusat kota dan daerah wisata Malioboro membuatnya sangat mudah diakses dan merupakan posisi yang strategis. Taman Budaya Yogyakarta atau yang dulu disebut dengan Purna Budaya, dibangun pertama kali pada tanggal 11 Maret 1977 di daerah kawasan Universitas Gadjah Mada. Taman Budaya dibangun kembali pada tahun 2002 di Kawasan Gondomanan. Fungsi dari Taman Budaya Yogyakarta adalah sebagai pusat budaya termasuk di dalamnya pengembangan dan pengolahan pusat dokumentasi, etalase, dan informasi seni budaya dan pariwisata (Sari et al., 2020). 
Pembangunan sebuah kota dalam perkembangannya memiliki kaitan erat dengan kebutuhan masyarakat akan ruang publik/public space. Guna menciptaan ruang publik yang sesuai dengan kebutuhan masyarakat, perlu dikaji mengenai kebutuhan dasar masyarakat di kota itu. Ruang publik tersebut menjadi salah satu kebutuhan dasar ruang bagi masyarakat yang dapat digunakan baik secara langsung atau dalam kurun waktu yang terbatas, maupun tidak langsung atau dalam kurun waktu tidak tertentu. Selain menjadi kebutuhan dasar masyarakat kota, ruang terbuka publik juga memberikan identitas tersendiri bagi kota, ruang publik juga berfungsi sebagai wadah interaksi sosial masyarakat seperti mengadakan suatu perayaan, berdagang, atau hanya sekedar menghabiskan waktu luang (Damayanty et al., 2018). Kaitannya dengan fungsi tersebut sangatlah penting dipertimbangkan bagaimana suatu ruang publik dapat menjadi wadah atau tempat berlangsungnya interaksi sosial antar pengunjung, sehingga adanya fasilitas-fasilitas yang mendukung sangat diperlukan di dalam suatu ruang publik.

Kota juga diharapkan dapat menjadi kota yang bersahabat. Oleh karena itu dalam merancanng sebuah kota diperlukan prinsip-prinsip yang membantu mewujudkan kota yang bersahabat tersebut. Adapun 10 prinsip urban design menurut (Tibbald,1993) dalam mewujudkan kota yang bersahabat, yaitu:

\section{1. "Places" matter most \\ 2. What are the lessons from the past \\ 3. Mixing uses and activities \\ 4. Human scale \\ 5. Pedestarian freedom \\ 6. Accsess for all \\ 7. Making it clear \\ 8. Lasting environment \\ 9. Controlling change \\ 10. Joining it all together}

Mengacu pada pembangunan kota yang bersahabat, adanya ruang publik seharusnya tidak hanya hadir secara fisik akan tetapi dapat memberi rasa atau makna tersendiri bagi kota ("places" matter most), bagaimana suatu ruang publik dapat memenuhi kebutuhan masyarakat kota akan adanya sebuah wadah interaksi sosial antar masyarakat. Makna sendiri terbentuk melalui kemampuan berfikir, dimana kemampuan berfikir setiap individu berbeda tergantung kapasitas dan kemampuan kognitif atau muatan informasi yang dimiliki. Perbedaan ini menimbulkan pemaknaan yang berbedabeda pula pada setiap individu meskipun obyek yang dihadapinya sama. Pemaknaan terjadi karena cara dan proses berfikir adalah sesuatu yang unik pada setiap individu yang akan menghasilkan keragaman dalam pembentukkan makna (Maharani, 2014). Taman Budaya Yogyakarta sendiri memiliki pemaknaan yang berbeda-beda yang dapat diketahui melalui motif, pengalaman, dan pandangan masing-masing individu. Ketiga faktor ini mempengaruhi bagaimana pemaknaan yang muncul terhadap Taman Budaya Yogyakarta.

Pemaknaan suatu objek hasil budaya masyarakat selalu berkembang seiring dengan waktu. Dapat dikatakan bahwa tidak ada makna yang tetap dan terus melekat pada sebuah objek. Makna akan selalu berubah seiring dengan perubahan waktu, budaya, dan pelaku budaya (Zaman, 2018). Memahami konsep makna perlu dilakukan secara mendalam. Pengenalan dengan subjek yang berinteraksi langsung pada objek akan membantu dalam mengetahui makna yang terbentuk (Saraswati, 2016). Pengunjung dapat memaknai Taman Budaya Yogyakarta apabila melakukan interaksi secara sadar dengan TBY.

Makna lingkungan akan muncul jika seseorang dapat memberikan reaksi terhadap lingkungan. Makna juga dijadikan sebagai pusat dari pengertian tentang bagaimana suatu lingkungan bekerja. Tingkatan makna dapat dibagi menjadi tiga yaitu:

1. Makna "tingkat tinggi"

Berkaitan dengan pandangan hidup, system filosofis, skema kultural, kosmologi, serta yang suci dan sebagainya.

2. Makna "tingkat menengah" Berkaitan dengan status, komunikasi identitas, kekuatan dan sebagainya.

3. Makna istrumental dan sehari-hari "tingkat rendah"

Berkaitan dengan pengguna seting dalam situasi sosial, perilaku yang diharapkan seperti: privasi, aksesibilitas.

Permasahan utama yang terjadi adalah dimana keberadaan suatu ruang publik tidak hanya dalam bentuk fisik saja akan tetapi dapat memberi rasa atau makna tersendiri bagi kota ("place" matter most), bagaimana suatu ruang publik dapat memenuhi kebutuhan masyarakat kota akan adanya sebuah wadah interaksi sosial antar masyarakat. Taman Budaya Yogyakarta merupakan ruang publik yang dijadikan masyarakat sebagai tempat berekreasi serta aktivitas seni dan kebudayaan. Tujuan penelitian ini adalah mengetahui 
bagaimana makna ataupun nilai dari Taman Budaya Yogyakarta bagi masyarakat mengingat keberadaannya sebagai pusat kesenian dan kebudayaan di Yogyakarta.

\section{METODE PENELITIAN}

Metode penelitian menggunakan paradigma interpretivisme. Berdasarkan pengalaman dan cara pandang orang yang diteliti paradigma interpretivisme mencoba mencari kejelasan tentang peristiwa-peristiwa sosial budaya yang dialami. Interpretif melihat fakta sebagai sesuatu yang unik dan memiliki makna khusus sebagai pokok penting dalam memahami makna sosial.

Pendekatan kualitatif merupakan pendekatan yang dilakukan dalam penelitian ini. Pendekatan kualitatif merupakan tata cara penelitian yang hasilnya berupa data-data deskriptif berupa lisan dari orang-orang, katakata tertulis, dan perilaku yang diamati.

Strategi penelitian yang digunakan yaitu strategi deduktif dan induktif. Strategi deduktif merupakan proses pendekatan yang berangkat dari kebenaran yang bersifat umum mengenai suatu fenomena (teori) kemudian menggeneralisasi kebenaran tersebut pada suatu peristiwa atau data tertentu yang mempunyai ciri yang sama dengan fenomena yang bersangkutan, dengan memakai kaidah logika tertentu (Azizah, 2013). Adapun teori yang digunakan dalam penelitian ini adalah pemaknaan ruang terbuka publik dapat diketahui melalui tiga aspek yaitu motif, pengalaman, dan pandangan dari masingmasing individu. Sedangkan strategi induktif yaitu metode yang membahas masalah khusus menuju ke arah kesimpulan yang bersifat umum (Azizah, 2013). Dalam penelitian ini metode induktif yaitu data yang diperoleh dari masing-masing responden dibahas dan disimpulkan menjadi kesimpulan yang bersifat umum.

\section{Metode Pengumpulan Data}

\section{Penelitian Survei}

Merupakan penelitian yang bersifat alamiah karena tidak melakukan perlakuan terhadap tempat yang dilteliti. Perlakuan peneliti hanya sebatas alat pengumpulan data, misalnya kuesioner, tes,wawancara terstruktur. Proses yang dilakukan dalam penelitian ini adalah dengan melakukan wawancara secara online (melalui aplikasi WhatsApp) kepada responden yang pernah berkunjung dan berinteraksi langsung dengan obyek penelitian.

\section{Studi Pustaka}

Studi pustaka yaitu proses mencari data dan informasi baik tertulis, foto, gambar, maupun dokumen elektronik. Proses yang dilakukan adalah dengan melakukan pencarian artikel jurnal, tesis, dan skripsi yang memuat data maupun informasi yang diperlukan untuk penelitian ini.

\section{Pemilihan Responden}

Pemilihan responden dilakukan dengan teknik purposive sampling. Teknik purposive sampling merupakan teknik dimana peneliti menentukan pengambilan sampel dengan cara menetapkan ciri-ciri khusus yang sesuai dengan tujuan penelitian sehingga diharapkan dapat menjawab permasalahan penelitian. Dalam penelitian ini, subyek yang dipilih adalah responden yang pernah berkunjung ke Taman Budaya Yogyakarta dan berinteraksi langsung dengan obyek penelitian.

Kriteria responden dalam penelitian ini adalah mahasiswa dan mahasiswi yang berasal dari luar DIY yang berlaku sebagai pengunjung Taman Budaya Yogyakarta. Alasan memilih responden dari luar Yogyakarta adalah untuk mengetahui apakah Taman Budaya Yogyakarta sebagaimana fungsinya sebagai pusat kebudayaan dan kesenian di Yogyakarta berhasil memberikan gambaran serta mengenalkan bagaimana budaya dan kesenian DIY kepada pengunjung mengingat TBY merupakan jendela bagi wisatawan untuk mengetahui keseluruhan budaya dan kesenian DIY. Adapun penentuan responden sejumlah 5 orang karena mewakili 5 (lima) kategori jumlah kunjungan wisatawan khususnya mahasiswa dan mahasiswi ke TBY. Dimana Responden 1 memiliki jumlah kunjungan sebanyak 1 kali, responden 2 memiliki jumlah kunjungan sebanyak 2-3 kali, responden 3 memiliki jumlah kunjungan 4-5 kali, responden 4 memiliki jumlah 6-7 kunjungan, dan responden 5 dengan jumlah kunjungan lebih dari 7 kali. 


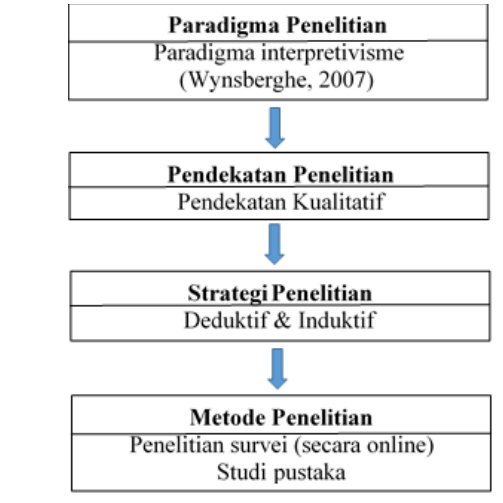

Bagan 1 Kerangka Metode Penelitian Sumber: Analisis Penulis

\section{Metode Analisis Data}

Data teks yang terkumpul dari pertanyaan terbuka, dianalisis dengan analisis data kualitatif. Analisis dilakukan melalui tiga tahap yaitu reduksi data (data reduction), pengorganisasian (organisation), dan interpretasi data (interpretation) (Fielding dan Fielding, 2008; Sarantakos, 1993). Reduksi data diartikan sebagai suatu proses mengidentifikasi data mentah (raw data) yang telah diperoleh dengan melakukan kategorisasi (categorising). Pengorganisasian diartikan sebagai proses mengumpulkan atau menyatukan informasi data yang dihasilkan dari identifikasi awal (proses reduksi data). Hasil analisis dari langkah reduksi data dan pengorganisasian tersebut selanjutnya dilakukan interpretasi data. Interpretasi data ini sangat penting untuk menghasilkan kesimpulan berdasarkan pertanyaan penelitian (Junaid, 2018).

\section{HASIL DAN PEMBAHASAN}

Makna Taman Budaya Yogyakarta ini diketahui melalui 3 (tiga) aspek yaitu pandangan, pengalaman, dan motif masyarakat yang mengunjungi TBY, sehingga nantinya akan disimpulkan bagaimana makna TBY bagi responden.

Berdasarkan data yang diperoleh dari 5 (lima) responden diketahui bahwa pandangan, pengalaman, dan motif tiap pengunjung terhadap TBY berbeda-beda, sehingga pemaknaan terhadap Taman Budaya Yogyakarta juga berbeda-beda. Namun terdapat beberapa kesamaan pandangan, pengalaman, dan motif dari kelima responden.

\section{Motif Pengunjung terhadap Taman Budaya Yogyakarta}

Berdasarkan data yang diperoleh responden memiliki jawaban yang beragam terkait motifnya mengunjungi Taman Budaya Yogyakarta, yaitu ingin mencari hiburan bertema budaya, ingin mencicipi kuliner yang ada, menyaksikan pertunjukan, mengikuti pasar kangen, menonton theater dan pameran, sekedar ingin jalan-jalan, serta melaksanakan kewajiban dalam tugas Presentasi Arsitektur.

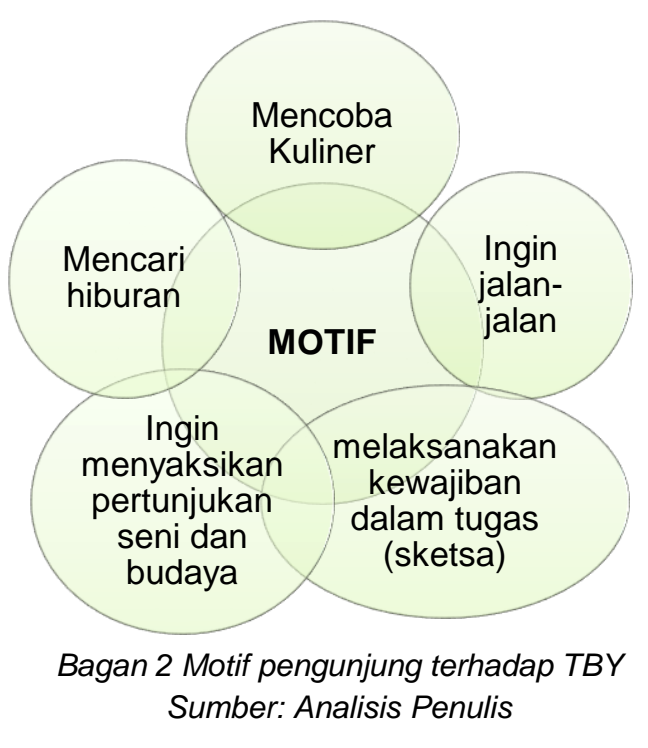

\section{Pengalaman Pengunjung terhadap Taman Budaya Yogyakarta}

Berdasarkan data yang diperoleh responden memiliki jawaban yang beragam terkait pengalamannya mengunjungi Taman Budaya Yogyakarta, yaitu mengikuti pertunjukan seni termasuk pameran dan theater, mengikuti festival budaya, membuat sketsa tugas, dan mengikuti pasar kangen.

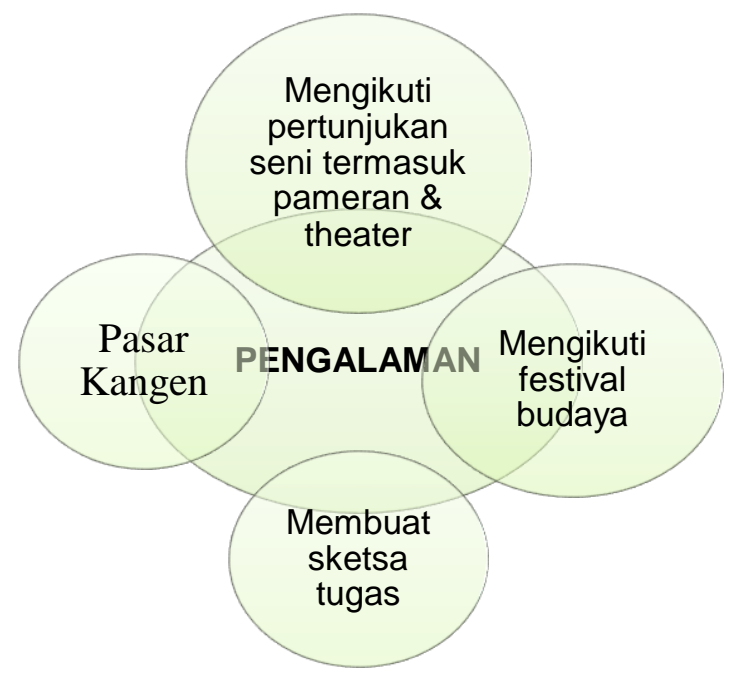

Bagan 3 Pengalaman pengunjung 
terhadap TBY

Sumber: Analisis Penulis

\section{Pandangan Pengunjung terhadap Taman Budaya Yogyakarta}

Berdasarkan data yang diperoleh responden memiliki pandangan yang beragam terhadap Taman Budaya Yogyakarta, yaitu Taman Budaya Yogyakarta merupakan tempat yang bersejarah, tempat diadakannya acara-acara kebudayaan, tempat diadakan acara-acara kesenian, dan tempat diselenggarakannya pasar kangen.

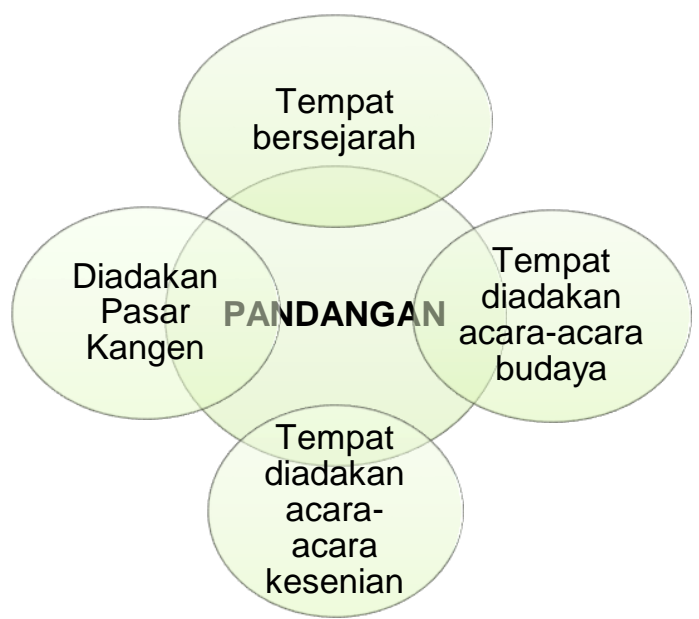

Bagan 4 Pandangan pengunjung terhadap TBY Sumber: Analisis Penulis

\section{Makna Taman Budaya Yogyakarta bagi Pengunjung}

Berdasarkan motif, pengalaman, dan pandangan dari masing-masing responden diketahui bahwa makna Taman Budaya Yogyakarta berbeda-beda yaitu memiliki makna kultural, makna sosial, makna pentingnya relasi antar manusia, dan makna harmonisasi kehidupan sosial dan budaya.

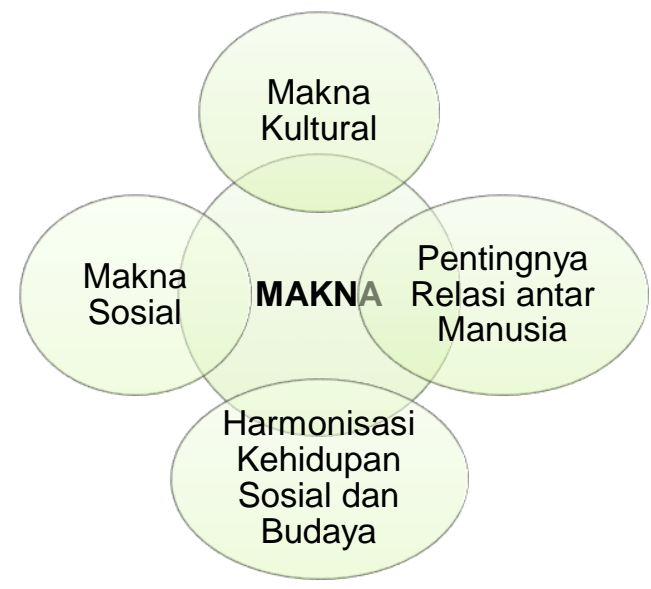

Bagan 5 Makna TBY

Sumber: Analisis Penulis

\section{Makna suatu ruang publik juga terbentuk} dari tatanan serta keadaaan fisik ruangnya

Taman Budaya Yogyakarta terbagi menjadi tiga ruang yaitu Concert Hall Taman Budaya (berfungsi sebagai tempat diskusi sastra, pameran, dan pelatihan), Gedung Societet Militair (berfungsi sebagai tempat pentas theater, tari, musik, dan pertunjukan seni lainnya), dan Halaman Taman Budaya Yogyakarta (berfungsi sebagai wadah panggung terbuka untuk acara seni dan musik malam, serta tempat diadakannya pasar kangen).

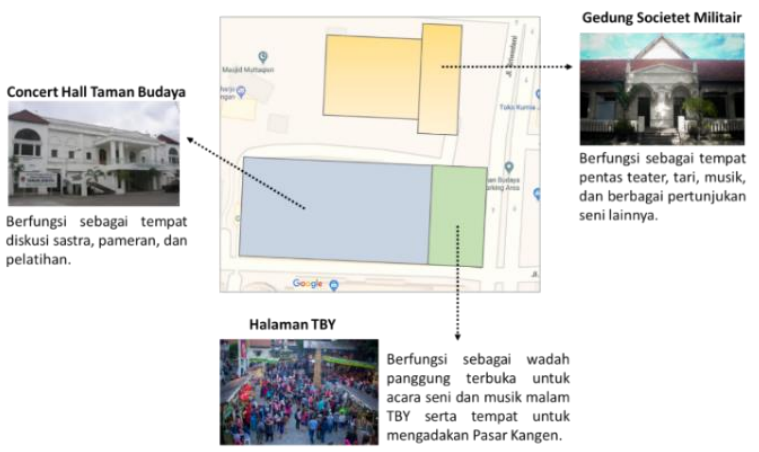

Gambar 1 Tatanan dan Fungsi Ruang TBY

Sumber: Diolah kembali oleh penulis dari google maps

Berdasarkan data yang diperoleh, berikut tatanan serta keadaan fisik ruang yang mempengaruhi pemaknaan masing-masing responden.

\section{Makna Sosial-Pentingnya Relasi Individu dengan Lingkungan (Jumlah kunjungan ke TBY 1 kali)}

Berdasarkan pandangan, pengalaman, dan motif pemaknaan Taman Budaya Yogyakarta dengan jumlah kunjungan seseorang sebanyak 1 kali memiliki makna sosial yaitu relasi individu dengan lingkungannya. 


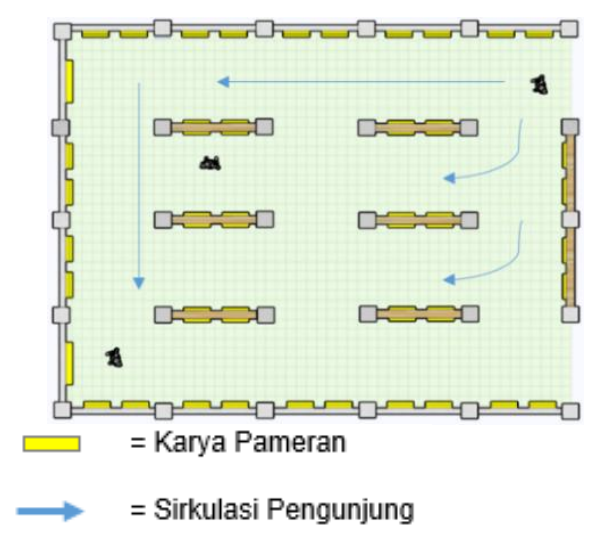

Gambar 2 Tatanan Ruang Concert Hall TBY Sumber: Analisis Pribadi

Tatanan ruang yang menarik dan teratur dapat menciptakan hubungan yang baik antara individu dengan lingkungan (ruang pameran). Banyaknya hasil karya seniman yang menarik di pameran dapat menjadi sumber inspirasi dan daya cipta bagi individu tersebut.

Makna Pentingnya Relasi Antar Manusia (Jumlah kunjungan ke TBY 2-3 kali)

Pemaknaan Taman Budaya Yogyakarta dengan jumlah kunjungan seorang pengunjung sebanyak 2-3 kali memiliki makna pentingnya relasi antar manusia (terjalin melalui komunikasi antar penjual dan pembeli di Pasar Kangen, serta interaksi antara seniman dan penonton saat pertunjukan).

Terciptanya relasi yang baik terlihat dari interaksi sosial dan budaya yang terjalin saat pertunjukan seni. Tatanan ruang yang ada mendukung terciptanya interkasi antara pelaku seni dan pengunjung.
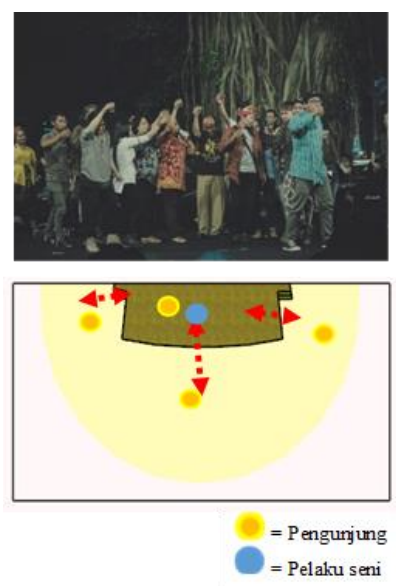

Gambar 3 Pentas Budaya dan Kesenian TBY Sumber: https://tby.jogiaprov.go.id/booking/ \& Analisis Pribadi
Terciptanya relasi antara penjual dan pembeli terlihat dari interaksi sosial yang terjalin saat diadakannya Pasar Kangen. Tatanan ruang yang ada mendukung terciptanya interaksi antara penjual dan pembeli. Dimana tidak ada batasan antara penjual dan pembeli.
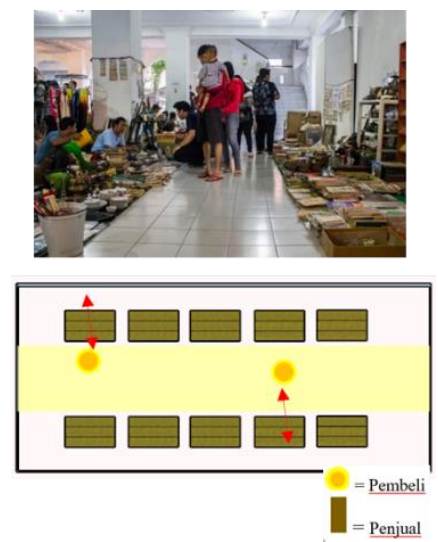

Gambar 4 Pasar Kangen TBY

Sumber: https://www.Ipmvisi.com/2016/07/ \& Analisis Pribadi

\section{Makna Kultural (Jumlah kunjungan ke TBY 4-5 kali)}

Pemaknaan Taman Budaya Yogyakarta dengan jumlah kunjungan seorang pengunjung sebanyak 4-5 kali memiliki makna kultural yaitu bagaimana TBY berhasil menyampaikan atau mengenalkan budaya dan kesenian yang ada di Yogyakarta.

Pemaknaan tersebut dapat terlihat dari keadaan fisik ruangnya:

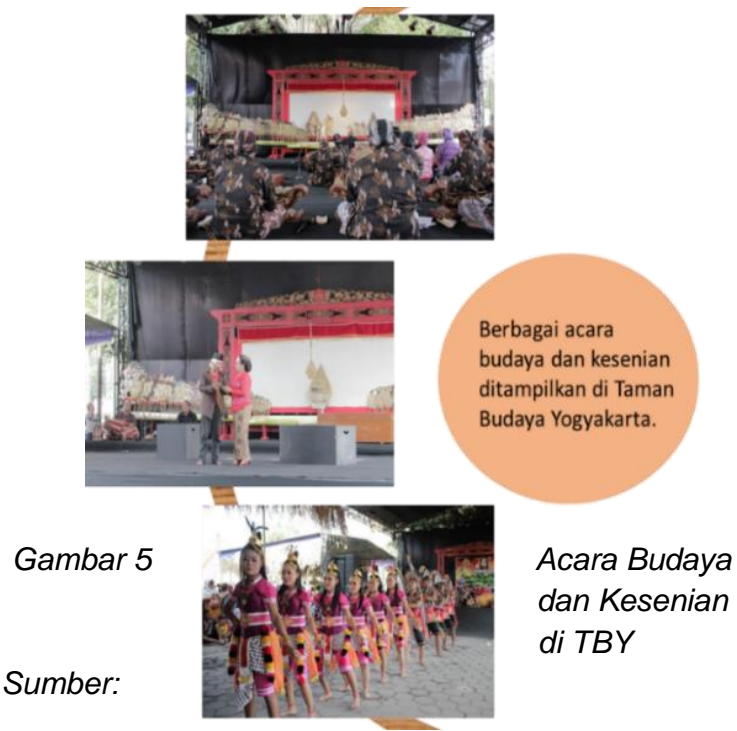

https://tby.jogjaprov.go.id/foto.html

Makna Harmonisasi Kehidupan Sosial dan Budaya (Jumlah kunjungan ke TBY 6-7 kali) 
Pemaknaan Taman Budaya Yogyakarta dengan jumlah kunjungan seorang pengunjung sebanyak 6-7 kali memiliki makna harmonisasi kehidupan sosial dan budaya.

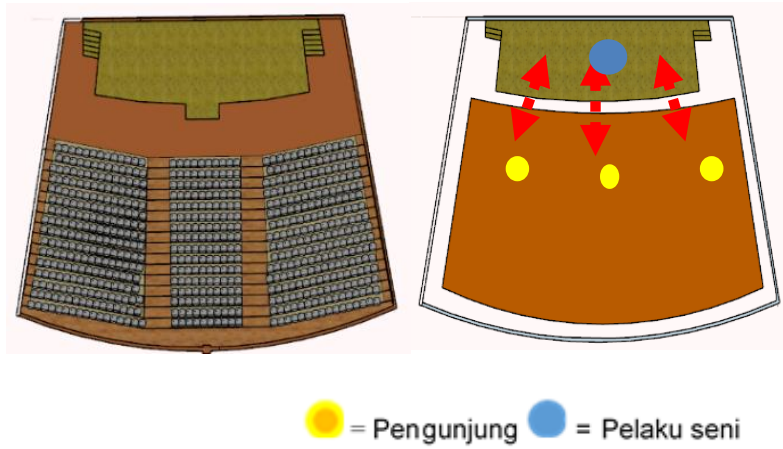

Gambar 6 Tatanan Ruang Concert Hall TBY Sumber: Analisis Pribadi

Harmonisasi kehidupan sosial budaya terlihat dari interaksi sosial dan budaya yang terjalin saat pertunjukan seni. Tatanan ruang yang ada mendukung terciptanya interaksi antara pelaku seni dan pengunjung.

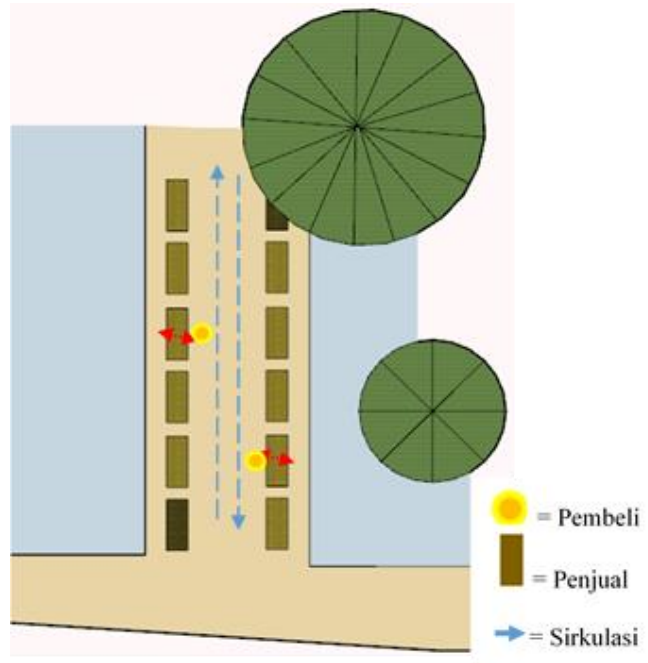

Gambar 7 Tatanan Ruang Concert Hall TBY Sumber: Analisis Pribadi

\section{Makna Kultural dan Sosial (Jumlah ke TBY kunjungan lebih dari 7 kali)}

Pemaknaan Taman Budaya Yogyakarta dengan jumlah kunjungan seorang pengunjung sebanyak lebih dari 7 kali memiliki makna kultural (sarana pengenalan budaya) serta makna sosial (terjalinnya kebersamaan antar pelaku seni dengan penonton)

Taman Budaya Yogyakarta sudah berpartisipasi dalam mengenalkan budaya dan kesenian Yogyakarta dan sudah menjadi salah satu tujuan wisata hiburan baik bagi wisatawan lokal maupun wisatawan mancanegara.

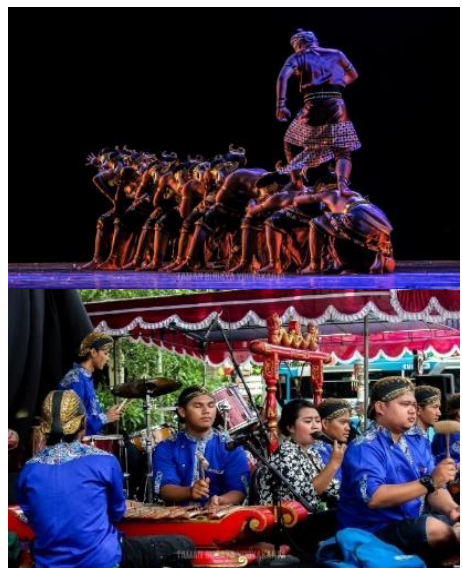

Gambar 8 Pentas Seni dan Kebudayaan di TBY Sumber: https://tby.jogjaprov.go.id/foto.html

Makna sosial yang terbangun terlihat dari terjalinnya kebersamaan antara pelaku seni dengan penonton, dimana tatanan ruang yang ada tidak menjadi pembatas antara pelaku seni dengan penonton untuk saling berinteraksi, selain itu juga bisa menciptakan interaksi antara sesama penonton

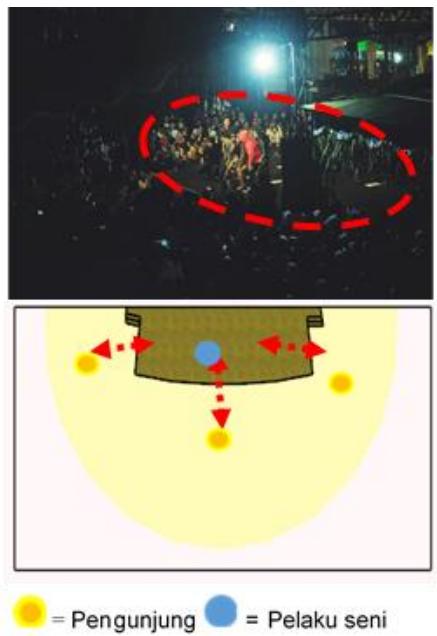

Gambar 9 Tata Ruang Pentas Seni di TBY Sumber: https://tby.jogjaprov.go.id/foto.html

\section{Hubungan Pandangan, Pengalaman, Motif, dan Makna Pengunjung terhadap Taman Budaya Yogyakarta}

Pengunjung memiliki pandangan masingmasing tentang TBY hal ini diperoleh dari pengalaman yang pernah dirasakan sebelumnya. Berdasarkan pengalaman yang pernah dirasakan oleh pengunjung sehingga bisa membawa pengunjung berkunjung kembali ke TBY. Hal ini berkaitan dengan terjadinya interaksi dan motif atau tujuan yang ada pada 
setiap individu (pengunjung), sehingga saatindividu mencapai tujuan dari motifnya, maka akan tercipta makna terhadap TBY oleh individu tersebut.

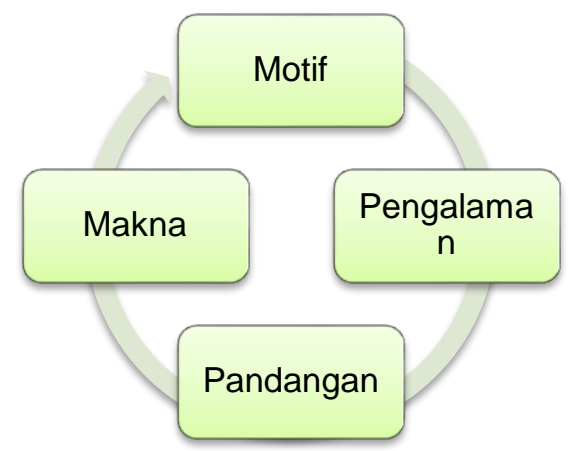

Bagan 6 Hubungan Pandangan, Pengalaman, Motif, dan Makna

Sumber: Analisis Penulis

Aspek yang memiliki keterkaitan erat dengan terciptanya makna merupakan motif, karena semua proses yang terjadi berawal dari motifnya. Motif merupakan upaya yang mendorong seseorang untuk mencapai tujuannya, sedangkan makna muncul jika tujuan seseorang berhasil terpenuhi.

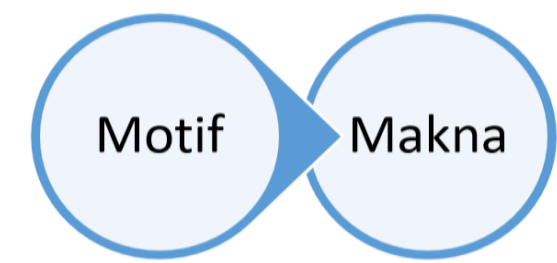

Bagan 7 Keterkaitan Aspek yang Paling Erat Sumber: Analisis Penulis

\section{KESIMPULAN}

Pemaknaan ruang publik Taman Budaya Yogyakarta berbeda-beda. Hal ini tergantung bagaimana pandangan, pengalaman, dan motif dari setiap pengunjung. Berdasarkan data yang diperoleh serta pembahasan yang telah dilakukan diperoleh kesimpulan bahwa Taman Budaya Yogyakarta tidak hanya hadir secara fisik saja tetapi sudah memberikan makna tersendiri bagi pengunjung, sehingga Taman Budaya Yogyakarta sudah memenuhi salah satu prinsip yang membantu mewujudkan kota yang bersahabat yaitu "places" matter most. Taman Budaya Yogyakarta memiliki makna kultural, makna sosial (interaksi individu dengan lingkungannya), makna pentingnya relasi antar manusia, dan memiliki makna harmonisasi kehidupan sosial dan budaya. Makna suatu ruang publik bisa terbentuk dari tatanan serta keadaaan fisik ruangnya.

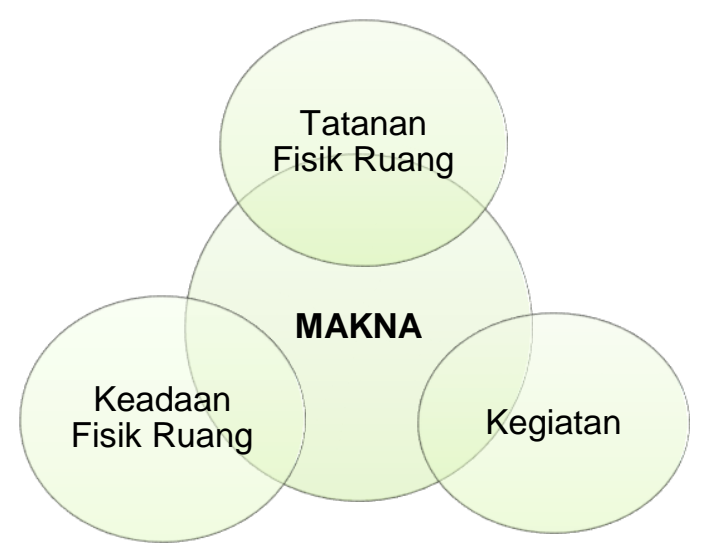

Bagan 8 Aspek yang Mempengaruhi Pembentukan Makna

Sumber: Analisis Penulis

Pemaknaan terhadap ruang publik juga dipengaruhi oleh jumlah kunjungan seseorang Semakin sering seseorang berinteraksi dengan suatu ruang publik, maka semakin dalam pemaknaannya terhadap ruang publik tersebut.

\section{UCAPAN TERIMA KASIH}

Melalui kesempatan ini, penulis ingin menyampaikan ucapan terima kasih kepada:

1. Narasumber-narasumber yang sudah bersedia untuk diwawancara dalam proses penelitian ini.

2. Semua pihak yang ikut serta membantu secara langsung maupun tidak langsung yang tidak dapat disebutkan satu persatu.

\section{DAFTAR PUSTAKA}

Azizah, C. (2013). Efektifitas Penerapan Slogan 6 S (Senyum Sapa Salam Salim Sopan Santun) Dalam Proses Pembentukan Karakter Di Smp Negeri 4 Surabaya. 6273.

Damayanty, N. ... Anggraini, R. (2018). Kajian Kesesuaian Penataan Ruang Terbuka Publik Di Kawasan Pasar Aceh Kota Banda Aceh Dengan Komponen Dan Indikator Perancangan Taman Kota Serta Rtrw Kota Banda Aceh 2009-2029. Jurnal Arsip Rekayasa Sipil Dan Perencanaan, 1(1), 53-62. https://doi.org/10.24815/jarsp.v1i1.10247

Junaid, I. (2018). Analisis Data Kualitatif Dalam Penelitian Pariwisata. 10(01), 59-74. https://doi.org/10.31219/osf.io/npvqu

Maharani, D. (2014). Makna Pariwisata Pulau Kemaro Menurut Pengunjung Dan 
Perilaku Komunikasinya. Jurnal Kajian Komunikasi, 2(1), 73-84. https://doi.org/10.24198/jkk.vol2n1.8

Saraswati, A. D. (2016). MAKNA MUSEUM BAGI PARA PENGUNJUNG (Studi Fenomenologi tentang Makna Museum Bagi Para Pengunjung Museum di Wilayah Surabaya). Libri-Net, 5(2), 27-28.

Sari, Y. K. ... Hapsari, R. R. (2020). Kolaborasi Kreatif Kegiatan Pariwisata Dan Pelestarian Budaya Di Taman Budaya Yogyakarta (Tby). Journal of Indonesian Tourism, Hospitality and Recreation, 3(1), 85-101.

https://doi.org/10.17509/jithor.v3i1.21853

Zaman, S. (2018). Pemaknaan Ruang Pada Masjid Kubah Emas: Kajian Semiotik Ruang. Paradigma, Jurnal Kajian Budaya, $7(2)$, 171. https://doi.org/10.17510/paradigma.v7i2.1 71 
